\title{
IMMUNOGLOBULIN INDICATORS TO VIRUSES CYTOMEGAL AND GENITAL HERPES IN THE BLOOD SERUM OF WOMEN WITH NON-ATIPICAL ENDOMETRIAL HYPERPROLIFETATIVE PATHOLOGY
}

DOI: 10.36740/WLek202008102

\author{
Nataliia E. Gorban, Irina B. Vovk, Iryna M. Nikitina, Valentina K. Kondratiuk, Nadiia 0. Yemets \\ 'STATE INSTITUTION «INSTITUTE OF PEDIATRICS, OBSTETRICS AND GYNECOLOGY NAMED AFTER ACADEMICIAN OM LUKYANOV ACADEMY \\ OF MEDICAL SCIENCES OF UKRAINE», KYIV, UKRAINE \\ ¿SUMY STATE UNIVERSITY, SUMY, UKRAINE \\ ${ }^{3}$ NATIONAL MEDICAL ACADEMY OF POSTGRADUATE EDUCATION NAMED AFTER PL SHUPIKA, KYIV, UKRAINE
}

\begin{abstract}
The aim of the study was to analyze the level of $\lg \mathrm{M}$ - and $\lg \mathrm{G}$-antibody (Ab) for cytomegalovirus (CMV) and herpes simplex virus type 2 (HSV-2) in serum of women with non-atypical endometrial hyperproliferative pathology.

Materials and methods: The analysis of immunoglobulin indices to CMV and HSV-2 in serum of women with non-atypical endometrial hyperproliferative pathology. In women with uterine body polyps the presence of CMV in the uterine cavity was found in $54.8 \%$ of cases, in women with non-atypical endometrial hyperplasia in $38.3 \%$ of cases. The levels of Ig G-Ab and Ig M-Ab to CMV in serum have a clear dependence on the degree of antigen expression in endometrial tissue. HSV-2 antigens were determined in 22.58 $\pm 5.31 \%$ of women with uterine body polyps and in $8.33 \pm 3.57 \%$ of patients with non-atypical endometrial hyperplasia while increasing serum specific antibodies to HSV- 2 . Results: The results indicate that there is a clear link between viral infection of hyperproliferatively altered endometrium and the determination of positive immunoglobulin levels in peripheral blood, which may be a reliable marker of chronic persistent viral infection in a woman's body.

Conclusions: In women with uterine body polyps, the presence of CMV in the uterine cavity was found in $54.84 \pm 6.32 \%$ of cases, in women with non-atypical endometrial hyperplasia in $38.33 \pm 6.28 \%$ of cases. The levels of $\mathrm{Ig} \mathrm{G}-\mathrm{Ab}$ and and $\mathrm{Ig} \mathrm{M}$-Ab to CMV in serum have a clear dependence on the degree of antigen expression in endometrial tissue. HSV-2 antigens were determined in $22.58 \pm 5.31 \%$ of women with uterine body polyps and in $8.33 \pm 3.57 \%$ of patients with non-atypical endometrial hyperplasia while increasing serum specific antibodies to HSV-2. The results indicate that there is a clear link between viral infection of the target tissue (hyperproliferatively altered endometrium) and the determination of a positive level of peripheral blood immunoglobulin, which may be a reliable marker of chronic persistent viral infection in a woman.
\end{abstract}

KEY WORDS: non-atypical endometrial hyperproliferative pathology, non-atypical endometrial hyperplasia, uterine body polyp, immunoglobulin to cytomegalovirus and genital herpes viruses

Wiad Lek. 2020;73(8):1600-1604

\section{INTRODUCTION}

Hyperproliferative pathology of the endometrium (uterine body polyps and endometrial hyperplasia) occupies a special place among the risk factors for endometrial cancer $[1,2]$. Despite numerous studies, neither the etiology nor the pathogenesis of endometrial hyperplastic processes has been elucidated to date, so treatment options are not fully substantiated.

Traditionally, the leading role in the pathogenesis of endometrial hyperplasia in patients of reproductive age is attributed to the increased estrogen concentrations arising from the absence or insufficient anti-estrogenic effect of progesterone [3]. The results of scientific researches of the last years testify in favor of infectious-inflammatory concept of developing the hyperplastic processes of genitals $[4,5,6]$. Chronic inflammatory diseases of the genitals are the basis for the occurrence of infertility, disorders of menstrual function, hyperplastic uterine processes and endometrium $[7,8]$.
Activation of chronic latent persistence of herpes viruses leads to the development of a certain symptom complex with impaired function of the female reproductive system, where there are inflammatory processes, and the growth of indigenous, sometimes pathogenic micro flora [9]. The cytomegalovirus causes nonspecific activation of B lymphocytes, acting as a polyclonal activator. In addition, cytomegalovirus interacts with Toll receptors (TLRs) 7 and/or 9 on DC cells, resulting in the production of IFN- $\alpha$ and B-cell proliferation [10].

It is known that an objective indicator of the course dynamics of infectious viral process may be the ratio of levels of Ig M- and Ig G-Ab to viral antigens in the blood serum [11].

\section{THE AIM}

To analyze the level of Ig M- and Ig G-Ab for cytomegalovirus and herpes simplex virus type 2 in serum of women with non-atypical endometrial hyperproliferative pathology. 


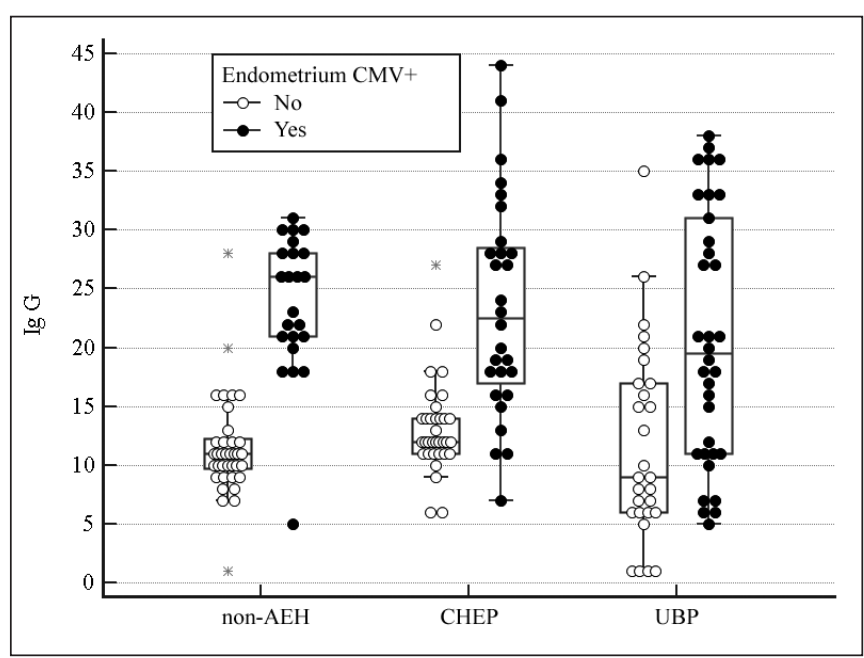

Figure 1. It shows the level of Ig G-Ab for CMV in serum in patients of reproductive age with various types of non-atypical hyperproliferative pathologies of the endometrium in the presence or absence of CMV antigens in the endometrium.

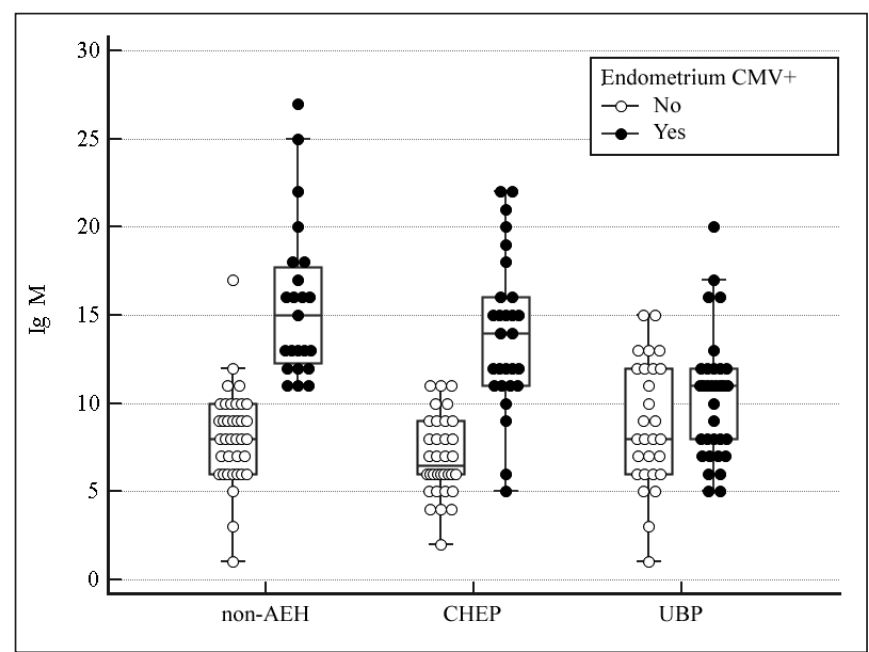

Figure 2. It shows the level of $\lg M-A b$ for CMV in serum in patients of reproductive age with various types of non-atypical hyperproliferative pathologies of the endometrium in the presence or absence of CMV antigens in the endometrium.

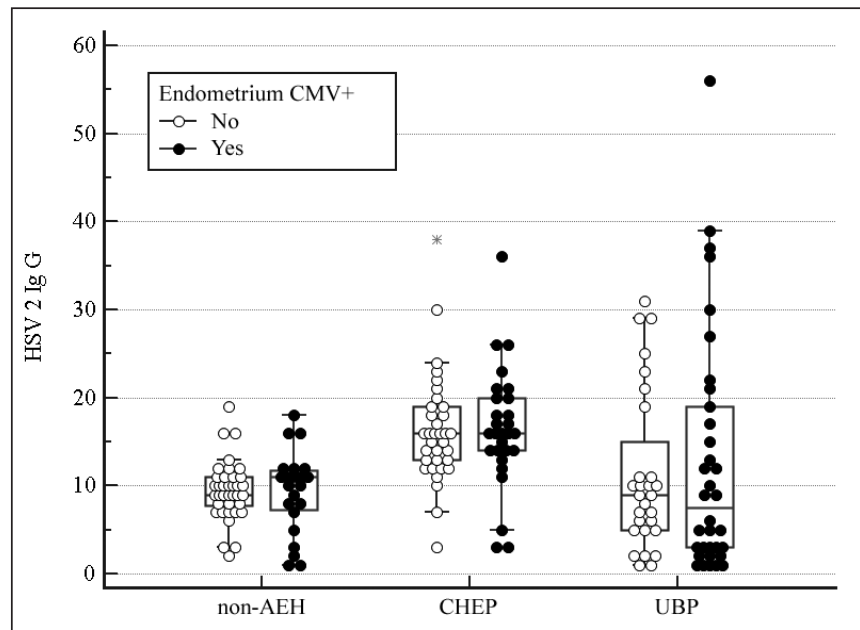

Fig. A.

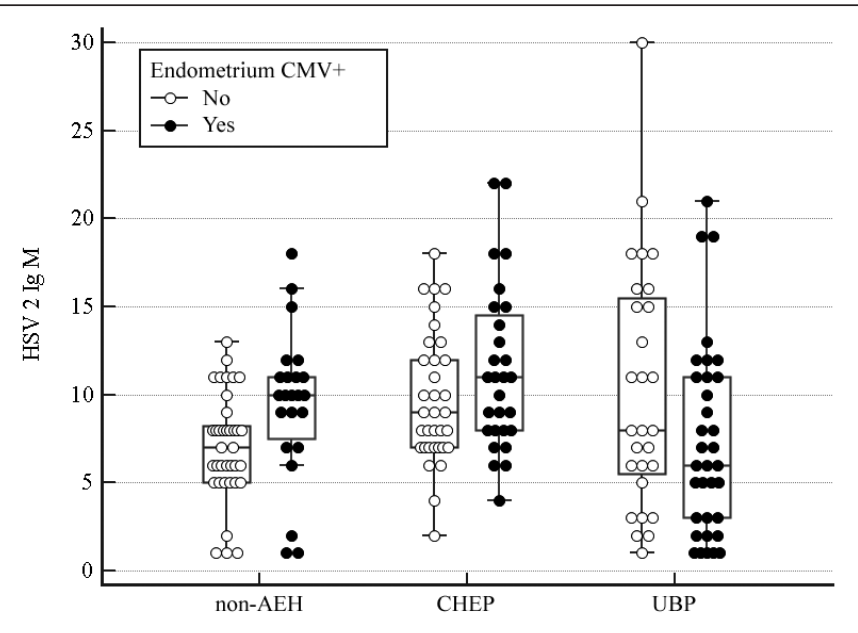

Fig. B.

Figure 3. The level of Ig G-Ab (Fig. A) and Ig M-Ab (Fig. B) for HSV-2 in serum of reproductive age patients with various types of non-atypical hyperproliferative pathology of the endometrium on the background of the presence or absence of CMV antigens in the endometrium.

\section{MATERIALS AND METHODS}

184 women of reproductive age were examined, divided into 3 main groups: Group I consisted of women with non-atypical endometrial hyperplasia (non-AEH) $(n=60)$; Group II - patients who had polyps of the uterine body (UBP) $(n=62)$; patients with combined hyperproliferative endometrial pathology (CHEP) (uterine body polyps and non-atypical endometrial hyperplasia) were included in group III $(n=62)$. The control group consisted of 30 healthy women.

An indirect Koon's method in modification using fluorescent dye-labeled monoclonal antibodies to CMV or HSV-2 was performed to determine the activity of the viral process in the tissue endometrial epithelium. The material was taken from the lesion center using a disposable probe with a cotton swab. Immediately after the material was collected, the test sample was applied in the form of a smear-print, touching the surface of the wells on a slide. For 5 min the smear was air-dried at a temperature of $22 \pm 2{ }^{\circ} \mathrm{C}$, after which it was fixed in $96 \%$ ethanol for $5 \mathrm{~min}$. Indirect immunofluorescence reaction was performed according to the diagnostic kits instruction. Solid-phase enzyme-linked immunosorbent analysis - allowed assessing the nature and intensifying the humoral immunity against CMV and HSV-2 (serum specific antibody levels - Ig M, Ig G; reference values: $<9$ conventional units (c.u.) - negative result, $>11$ c.u. - positive result, «gray area» 9-11 c.u.). Enzyme-linked immunosorbent system test of the Novum diagnostic company (Germany) were used.

\section{RESULTS AND DISCUSSION}

In patients with non-atypical endometrial hyperplasia whose CMV antigens were detected in endometrial tissue, the level of 
specific antibodies to CMV in serum was significantly higher than in patients whose CMV antigens were not detected at the locus. In particular, the middle level of Ig M-Ab to CMV in women with non-atypical endometrial hyperplasia and endometrial infection with CMV virus was 15.0 (12.25 - 17.75) c.u., the Ig G-Ab level was 26.0 (21 - 28) c.u. In patients of the same group, without $\mathrm{CMV}$ infection, Ig M-Ab level was 8.0 (6 - 10) c.u., Ig G-Ab level - 11.0 (9.75 - 12.25) c.u., which had a difference at the significance level $(\mathrm{p} \leq 0.001)$.

In the group of patients with uterine body polyps on the background of CMV infection of the endometrium, a significantly higher level of serum Ig G-Ab was also determined making 19.5 (11 - 31) c.u, compared with $9(6$ - 17) c.u in women of this group, in whose endometrium no CMV antigens were identified and it was excellent at the level $(\mathrm{p}=0.008)$. There was no statistical difference in the Ig M-Ab concentrations for CMV in the serum of the subjects surveyed, since in women with CMV-infected endometrial tissue the index was $11(8-12)$ c.u, and without CMV detection at the locus only $8(6-12)$ c.u. $(\mathrm{p}=0.17)$.

In patients with combined non-atypical endometrial hyperproliferative pathology with CMV antigens in endometrial tissue, levels of Ig M-Ab and Ig G-Ab to CMV significantly exceeded those of women in the same endometrial group who did not find Ig antigens - 14 (11 - 16) c.u. and Ig G-Ab - 22.5 (17 - 28.5) c.u. in contrast to the values of Ig M-Ab levels $6.5(6-9)$ c.u. and Ig G-Ab - $12(11$ - 14) c.u., respectively $(\mathrm{p} \leq 0.001)$.

Schematically, the levels of Ig M-Ab and Ig G-Ab to CMV in the examined patients are shown in Figures 1 and 2. The results obtained prove that the concentrations of both Ig ( $\mathrm{G}-\mathrm{Ab}$ and $\mathrm{Ig} \mathrm{M}-\mathrm{Ab}$ ) to CMV in the serum of the examined patients have a clear dependence on the degree of antigen expression in endometrial tissue.

In the group of patients with uterine body polyps, regardless of the presence or absence of CMV infection, endometrial Ig G- and Ig M-Ab to HSV-2 were mostly negative: Ig M-Ab - 6 (3 - 11) c.u. in women with CMV infection in the endometrium and 8 (5.5 - 15.5) c.u. without CMV infection in the endometrium, $(\mathrm{p}=0.08)$; Ig G-Ab - $7.5(3-19)$ c.u. and 9 (5 - 15) c.u. respectively ( $\mathrm{p}=0.71$ ).

In patients with non-atypical endometrial hyperplasia, the results of serum levels of Ig G-Ab to HSV-2 in the presence or absence of local CMV infection also had no differences, mainly being in the negative or weakly positive zone: 11 (7.25 - 11.75) c.u. and $9(7.75$ - 11) c.u., respectively, $p=0.58$. In the group of patients with non-atypical endometrial hyperplasia who had the expression of HSV-2 antigens in the endometrium, the level of Ig M-Ab to HSV-2 was 11 (10.75 - 13) c.u., against $8(6-10)$ c.u. in patients with a lack of local expression of HSV-2 antigens, with $\mathrm{p}=0.007$.

In the group with combined non-atypical hyperproliferative pathology of the endometrium in the serum of patients, the levels of Ig G- and Ig M-Ab to HSV-2 showed no differences and dependence on the state of infection of the endometrial tissue. In the case of positive expression of $\mathrm{CMV}$ antigens, the concentration of Ig G- and Ig M-Ab to HSV-2 was 16 (14 - 20) c.u. and $11(8-14.5)$ c.u. accordingly, and in the absence of
CMV in the endometrium, were detected at levels of 16 (1319) c.u. and 9 (7-12) c.u., respectively ( $\mathrm{p}=0.18$ for Ig $\mathrm{M}-\mathrm{Ab}$ and $\mathrm{p}=0.59$ for Ig $\mathrm{G}-\mathrm{Ab}$ ).

Schematically, the above data are shown in Figure 3.

In the group of patients with non-atypical endometrial hyperplasia who had expression of HSV-2 antigens in the endometrium, the level of Ig M-Ab to HSV-2 was 11 (10.75 - 13) c.u. vs. $8(6-10)$ c.u. in patients with no local expression of HSV-2 antigens at $p=0.007$. A similar distribution of levels was determined for Ig G-Ab to HSV-2 in this group of patients, amounting to $16(11-16.5)$ c.u. in women with endometrial HSV-2 infection and equal to $9(7-11)$ c.u. in patients, whose endometrium did not have HSV-2 antigens, which was determined to be different at the level, $\mathrm{p}=0,005$.

In patients with uterine polyps, similar unidirectional changes were noted. So, against the background of infection of HSV-2 endometrium, the levels of Ig M-Ab in the blood serum of such women were significantly higher - 12 (11 - 15) c.u. against $6(3-10.5)$ c.u. in the absence of viral detection in the endometrium, $\mathrm{p}=0$. In terms of Ig G-Ab, in the serum of patients with local expression of HSV-2 antigens - they were equal to $20(11-23)$ c.u., which was different from the indicator in patients without viral endometrial damage - 5.5 $(2-10,5)$ c.u., $(\mathrm{p}<0.001)$.

Patients with combined non-atypical hyperproliferative pathology of the endometrium also noted differences from patients who had local infection with HSV-2 and without its signs: the concentration of Ig M-Ab to HSV-2 was 15 (12 - 16) c.u. and $8.5(7-11)$ c.u. at $p<0.001$, the concentration of Ig G-Ab to HSV-2 is $22.5(19-26)$ c.u. in contrast to 15 $(12$ - 17) c.u., $(p<0.001)$. Visualization of the obtained ratios by immunoglobulin classes is presented in Figures 4 and 5 .

In the group of patients with non-atypical endometrial hyperplasia, which showed the presence of HSV-2 endometrial tissue infection, serum Ig G-Ab had sharply positive values, equal to $26(20,75-28,25)$ c.u., whereas in patients of the same group, without local viral infection, these levels were defined as slightly positive with values of $12(10-21.75)$ c.u., which had differences at the significance level $\mathrm{p}=0.02$.

As for the values of Ig M-Ab concentrations in the above group of patients, in the presence of HSV-2 - infection of endometrial tissue, this index was $16(12,75$ - 19) c.u., which was different from the value in $10(7,25$ - 12.75) c.u. in the absence of verification of HSV-2 antigens at the locus ( $\mathrm{p}=0.009)$.

Patients with polyps of the uterine body have no differences between the results of the major classes of serum immunoglobulin, depending on the presence or absence of infection of endometrial tissue HSV-2. Thus, in the examined of this group, both with and without endometrial tissue contamination with and with HSV-2 antigens, the levels of Ig G-Ab to CMV concentrations were slightly positive, being 10.5 (7 - 33) c.u. and $16(8.5-21)$ c.u., respectively, $p=0.91$. With regard to Ig M-Ab levels for CMV in patients with uterine body polyps, the mean values in the cohort of patients with signs of HSV2 infection at the locus were $11(7-13)$ c.u., which was not significantly different from $8.5(7-12)$ c.u. in the absence of endometrial infection, determined at almost negative levels, $\mathrm{p}=0.18$. In the case of viral CMV contamination of the endo- 


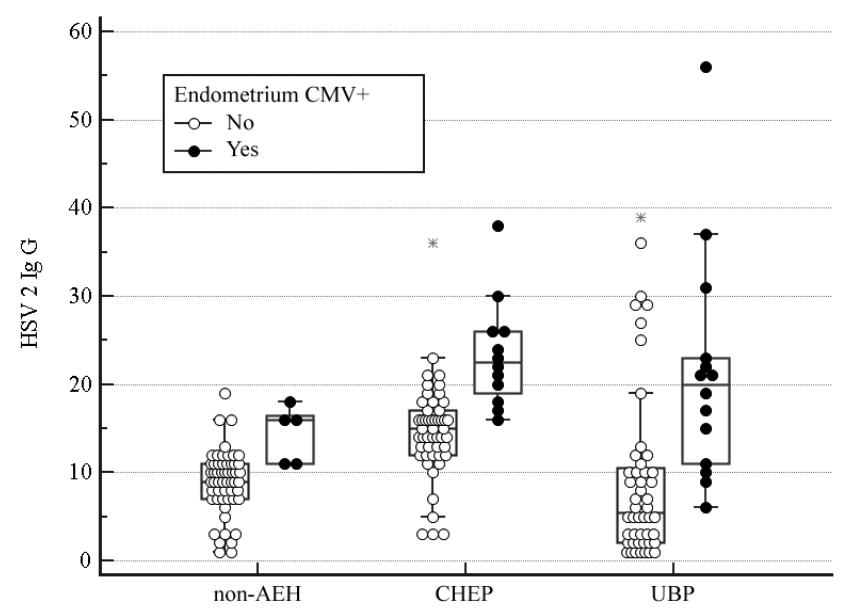

Figure 4. The level of Ig G-Ab for HSV-2 in serum of reproductive age patients with various types of non-atypical hyperproliferative pathology of the endometrium on the background of the presence or absence of HSV-2 antigens in the endometrium.

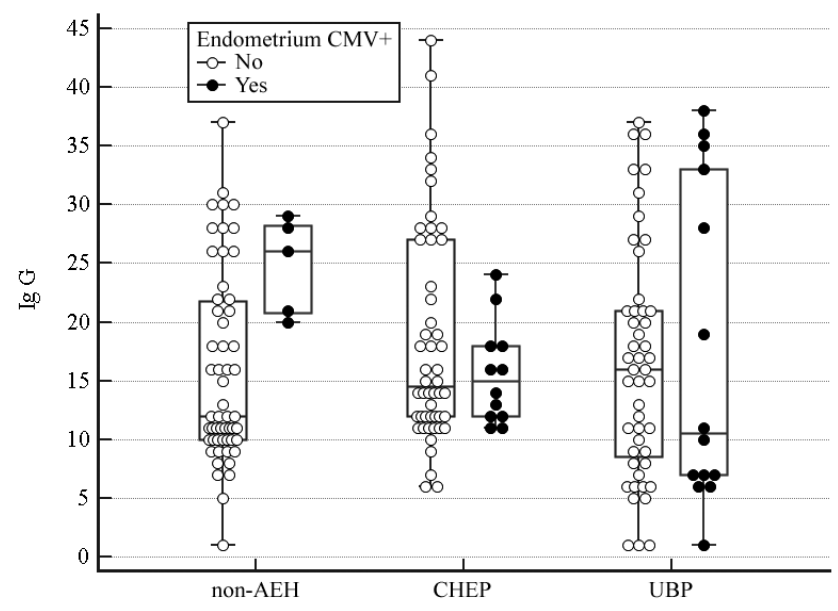

Figure 6. The level of $\mathrm{Ig}$ G-Ab for CMV in serum of reproductive age patients with various types of non-atypical hyperproliferative pathology of the endometrium on the background of the presence or absence of HSV-2 antigens in the endometrium.

metrium, the average concentration of Ig G-Ab to CMV was 15 (12 - 18) c.u., and in the absence of viral contamination at the locus, this indicator was equal to $14.4(12-27)$ c.u., which was almost the same, within slightly positive values, at $\mathrm{p}=0.66$.

The level of serum Ig M-Ab to CMV in patients with combined non-atypical endometrial hyperproliferative pathology in the case of HSV-2 infection was 11 (6.5 - 13) c.u., which did not differ from the negative index of $9(6-12)$ c.u. in the absence of endometrial infection HSV-2, $\mathrm{p}=0.75$.

The above results are graphically illustrated in Figures 6 and 7 . In the case of non-atypical endometrial hyperplasia in women of reproductive age with CMV lesions, the endometrial Ig G-Ab level in the blood was $26(21$ - 28) c.u., in the case of combined non-atypical endometrial hyperproliferative pathology - $22.5(17-28.5)$ c.u., in the presence of uterine body

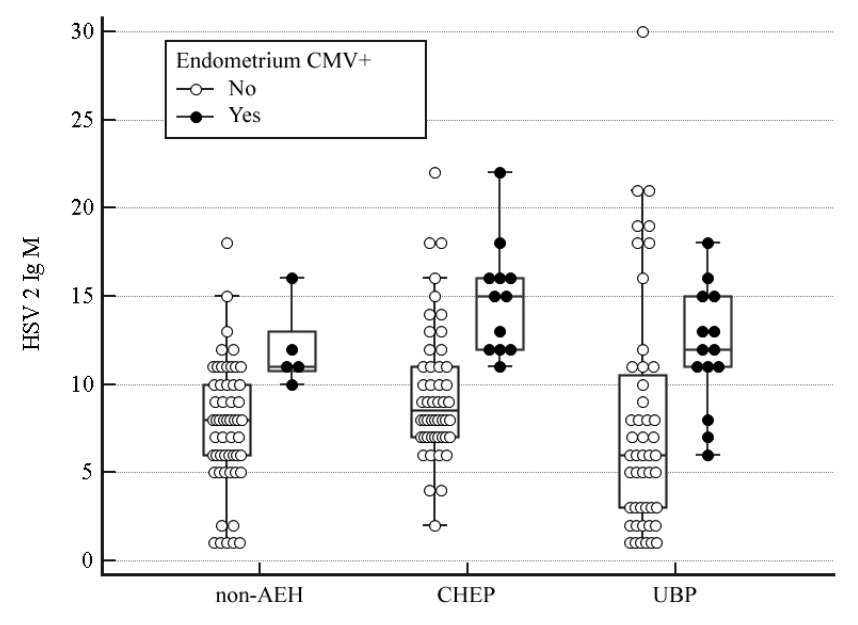

Figure 5. The level of Ig M-Ab for HSV-2 in serum of reproductive age patients with various types of non-atypical hyperproliferative pathology of the endometrium on the background of the presence or absence of HSV-2 antigens in the endometrium.

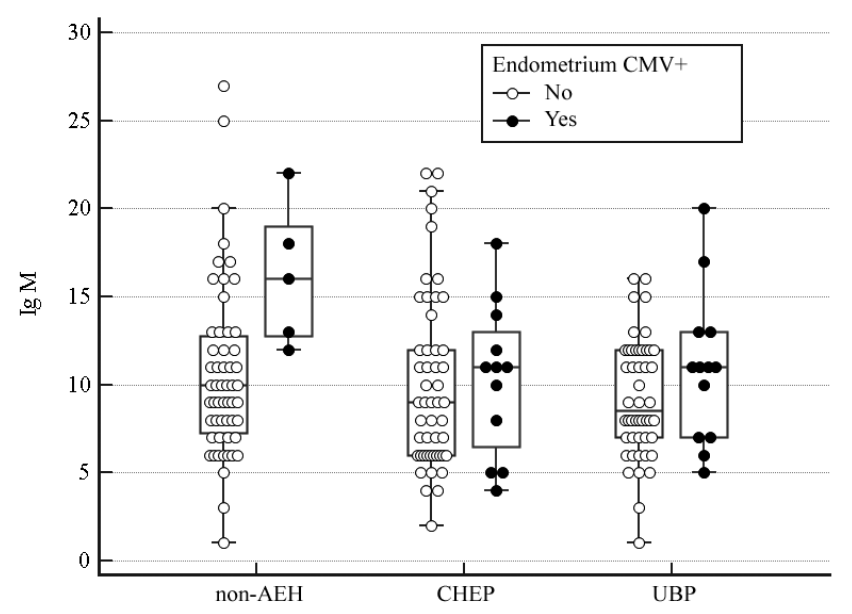

Figure 7. The level of $\mathrm{Ig} M-A b$ for $C M V$ in serum of reproductive age patients with various types of non-atypical hyperproliferative pathology of the endometrium on the background of the presence or absence of HSV-2 antigens in the endometrium.

polyps - 19.5 (11 - 31) c.u., which in all groups differed from the indicators in patients without viral endometrial damage.

When analyzing the virological profile of HSV-2 in serum and hyperplastically altered endometrial tissue, we also found positive Ig G-Ab. In the case of combined non-atypical hyperproliferative pathology of the endometrium, the level of Ig G-Ab was 22.5 (19 - 26) c.u., uterine body polyps - $20(11$ - 23) c.u., non-atypical endometrial hyperplasia - $16(11-16,5)$ c.u., which was different from those in patients where HSV-2 antigens were not detected in endometrial tissue.

With regard to Ig M-Ab values in patients with non-atypical endometrial hyperproliferative pathology, in most cases of viral lesions of the endometrial tissue, positive results were observed, but they did not always reach the diagnostic value and did not differ significantly from the results obtained in the patients. 
Thus, endometrial tissue infection with non-atypical hyperproliferative pathology of CMV antigens reflects the significant etiological role of this virus. The highest frequency of detection of CMV antigens in endometrial tissue was verified in the group of women with uterine body polyps - in 54,84 \pm $6,32 \%$ of cases, in $38,33 \pm 6,28 \%$ in non-atypical endometrial hyperplasia and in combination of these pathologies - in 45,16 $\pm 6.32 \%$ of patients.

Distributing the detection of HSV-2 antigens in the endometrium was determined in a significantly smaller number of women, but its distribution was similar to CMV infection. Thus, the smallest proportion was observed among women with non-atypical endometrial hyperplasia $(8.33 \pm 3.57 \%)$, and the largest was observed with uterine body polyps (22.58 $\pm 5.31 \%)$. In the group with combined non-atypical hyperproliferative pathology, endometrium HSV-2 antigens were found to be $19.35 \pm 5.02 \%$.

The proven relationship between the presence of target tissue infection by a viral agent and the determining its positive levels of Ig G-Ab concentrations in peripheral blood can be reliable evidence of the presence of chronic persistent viral infection in a woman's body.

\section{CONCLUSIONS}

In women with uterine body polyps, the presence of CMV in the uterine cavity was found in $54.84 \pm 6.32 \%$ of cases, in women with non-atypical endometrial hyperplasia in $38.33 \pm 6.28 \%$ of cases. The levels of Ig G-Ab and and Ig $\mathrm{M}-\mathrm{Ab}$ to $\mathrm{CMV}$ in serum have a clear dependence on the degree of antigen expression in endometrial tissue.

HSV-2 antigens were determined in $22.58 \pm 5.31 \%$ of women with uterine body polyps and in $8.33 \pm 3.57 \%$ of patients with non-atypical endometrial hyperplasia while increasing serum specific antibodies to HSV-2. The results indicate that there is a clear link between viral infection of the target tissue (hyperproliferatively altered endometrium) and the determination of a positive level of peripheral blood immunoglobulin, which may be a reliable marker of chronic persistent viral infection in a woman.

\section{REFERENCES}

1. Wilson PC, Buza N, Hui P. Progression of endometrial hyperplasia: a revisit under the 2014 WHO classifications Int J Clin Exp Pathol 2016;9(2):1617-1625.

2. Svincic'kyj VS, Renkas OP. Klinichni rekomendacii' z diagnostyky ta likuvannja raku endometrija. Klinichna onkologija. [Clinical recommendations about diagnostics and cancer therapy of endometrium. Clinical oncology]. 2018;T.8, 3(31):185-190.

3. Tabakman JuJu, Solopova AG, Bishtavi AH, Idrisova LJe. Giperplazija jendometrija: spornye voprosy patogeneza i terapii. [Endometrial hyperplasia: controversial issues of pathogenesis and therapy]. Akusherstvo, ginekologija i reprodukcija. 2016;10(3):5-10.

4. Bazhenova LG, Shramko SV, Sabancev MA, Guljaeva LF. Sovremennyj vzgljad na patogenez proliferativnyh zabolevanij matki. Rossijskij vestnik akushera-ginekologa. [A modern view of the pathogenesis of proliferative uterine diseases]. 2018;18(6):31-40.https://doi. org/10.17116/ rosakush20181806131
5. Vovk IB, Netreba NI, Gorban' NJe. Kompleksnyj pidhid do diagnostyky genital'nogo gerpesu u hvoryh iz retencijnymy kistamy jajechnykiv (operacijnyj material, statevi shljahy, syrovatka krovi). [Comprehensive piddid before diagnosis of genital herpes in patients with retention cysts (operative material, articles of hat, blood syrup)]. Zdorov'e zhenshhyny. 2011;7 (63):177-181.

6. Zapol's'kij MJe.Vlijanie gerpeticheskoj infekcii na razvitie somaticheskoj patologii. Gerpes-inducirovannye zabolevanija. [The effect of herpetic infection on the development of somatic pathology. Herpes-induced diseases]. Dermatologija ta venerologija. 2012;3(57):24-32.

7. Lax SF. Endometritis. Seltene erkrankung mit klinischer relevanz? Der Pathologe. 2016;37(6):521-525.

8. Fülöp T, Larbi A, Pawelec G. Human T cell aging and the impact of persistent viral infections. Frontiers in Immunology. 2013;4:1-9.

9. Abdulmedzhidova AG, Rog KV, Zavalishina LE, Kushch AA. Intrafollicular infection of mammals and human oocytes by the herpes simplex virus. Vopr. Virusol.2014;59(1):42-46.

10. Marques $M$, Ferreira AR, Ribeiro $D$. The interplay between Human cytomegalovirus and pathogen recognition receptor signaling.Viruses. 2018;10(10):514.

11. Pass RF, Arav-Boger R. Maternal and fetal cytomegalovirus infection: diagnosis, management, and prevention.F1000Res. 2018;7:255.

The work is carried out within the framework of the research work "Optimization of diagnosis and prevention of diseases of the reproductive system and development of pathogenically grounded methods for their correction" (state registration number 011U001801).

\section{ORCID and contributionship:}

Nataliia E. Gorban: 0000-0001-8175-6579 A,E,F

Irina B. Vovk: 0000-0003-4018-8506 ${ }^{B, D, C}$

Iryna M. Nikitina: 0000- 0001-6595-2502 ${ }^{D, F}$

Valentina K. Kondratiuk: 0000-0001-6220-2116 ${ }^{\text {FE }}$

Nadiia O. Yemets: 0000-0003-0852-8398 ${ }^{A, F}$

\section{Conflict of interest:}

Authors have no conflict of interests.

\section{CORRESPONDING AUTHOR \\ Iryna M. Nikitina}

Sumy State University

12, Rymskogo-Korsakova st.,

40030, Sumy, Ukraine

tel: +380662947360

e-mail:nikitina1med@gmail.com

Received: 09.02 .2020

Accepted: 15.06 .2020

A - Work concept and design, B - Data collection and analysis, C - Responsibility for statistical analysis,

$\mathbf{D}$-Writing the article, $\mathbf{E}-$ Critical review, $\mathbf{F}-$ Final approval of the article 